\title{
Faktor Penarik dan Pendorong Deforestasi Hutan di Kabupaten Dharmasraya, Sumatra Barat
}

\author{
Abdul Mutolib ${ }^{(1)^{*}}$, Yonariza ${ }^{(2)}$, Ali Rahmat ${ }^{(3)}$ \\ (1) Jurusan Agribisnis, Fakultas Pertanian, Universitas Lampung, Bandar Lampung, 35141 \\ (2) Jurusan Agribisnis, Fakultas Pertanian, Universitas Andalas, Padang, 25163 \\ (3) Jurusan IImu Tanah, Fakultas Pertanian, Universitas Lampung, Bandar Lampung, 35141 \\ *email korespondensi: amutolib24@yahoo.com
}

\begin{abstract}
This study aims to identify the pull factors and push factors of deforestation in the Production Forest Management Unit (PFMU) Dharmasraya. The study was conducted in January to July 2017. The research sites were at PFMU Dharmasraya, West Sumatra. Administratively, PFMU Dharmasraya located in Pulau Punjung and Koto Besar Sub Districts, Dhamasraya District, West Sumatra Province. PFMU Dharmasraya has a working area of around 33,550 ha. Area of PFMU Dharmasrayais a secondary forest whose territory borders on a residential area. Data collection combines several data collection techniques such as key informant interviews, field observations / transects, homestays in the forest and secondary data analysis. The number of key informants interviewed were 34 informants. The research method uses a qualitative research approach. Pull factors of deforestation at PFMU Dharmasraya includes the economic and institutional nature of forest resources, as well as easy access and sloping topography of forests. The push factor of local communities to cut the forest (deforestation) includes economic/employment needs through clearing the forests for plantation land and sources of income, opening up to mark property rights, and after the forest has been cut down and abandoned, and other factors are high wood demand and timber prices illegal logging in the forest which ultimately causes deforestation.
\end{abstract}

Keywords: PFMU Dharmasraya, Pull factors, Push factors, deforestation, plantations

\begin{abstract}
Abstrak. Penelitian ini bertujuan untuk mengidentifikasi faktor penarik dan pendorong deforestasi hutan di wilayah Kerja Kesatuan Pengelolaan Hutan Produksi (KPHP) Dharmasraya. Penelitian dilaksanakan pada Januari hingga Juli 2017. Lokasi penelitian berada di KPHP Dharmasraya, Sumatera Barat. Secara administrasi KPHP Dharmasraya terletak di Kecamatan Pulau Punjung dan Koto Besar, Kabupaten Dhamasraya, Provinsi Sumatera Barat. KPHP Dharmasraya memiliki wilayah kerja dengan luas sekitar 33.550 ha. Kawasan KPHP Dharmasraya merupakan hutan sekunder yang wilayahnya berbatasan dengan kawasan pemukiman penduduk. Pengumpulan data mengkombinasikan beberapa teknik pengumpulan data seperti wawancara key informant, observasi lapangan/transek, homestay di dalam hutan dan analisis data sekunder. Jumlah informan kunci yang diwawancarai sebanyak 34 informan. Metode penelitian menggunakan menggunakan pendekatan penelitian kualitatif. Faktor penarik deforestasi hutan di KPHP Dharmasraya meliputlsifat ekonomi dan institusi sumberdaya hutan, serta mudahnya akses dan topografi hutan yang landai. Faktor pendorong masyarakat melakukan penebangan hutan meliputi adalah kebutuhan ekonomi/lapangan kerja melalui pembukaan hutan untuk lahan perkebunan dan sumber pendapatan, pembukaan untuk menandai hak milik, serta Setelah hutan ditebang kemudian ditinggalkan, dan faktor lainnya adalah tingginya kebutuhan kayu dan nilai (harga) kayu sehingga masyarakat menebang kayu (illegal logging) di dalam hutan yang pada akhirnya menyebabkan deforestasi hutan.
\end{abstract}

Kata kunci: KPHP Dharmasraya, Faktor penarik, Faktor pendorong, deforestasi, perkebunan

\section{Pendahuluan}

Deforestasi merupakan ancaman serus bagi hutan di Indonesia. Dalam beberapa kajian, Deforestasi di Indonesia disebabkan oleh banyak hal, seperti tekanan ekonomi dan pertumbuhan penduduk [1], tekanan pertanian dan perkebunan [2] [3], illegal logging [4], pembangunan perkebunan kelapa sawit [5], pembangunan 
perumahan, pembukaan jalan, dan kebakaran hutan [6] [7].

Penelitian ini difokuskan di wilayah Kesatuan Pengelolaan Hutan Produksi Dharmasraya (KPHP Dharmasraya) yang mengalami deforestasi sangat cepat. Deforestasi hutan telah terjadi ketika hutan dibebani IUPHHK-HA. Dalam beberapa penelitian, IUPHHKHA dianggap sebagai penyebab utama deforestasi hutan di Indonesia (Afrizal, 2009; Purba et al., 2014). Deforestasi kemudian terjadi ketika pemerintah melakukan konversi hutan melalui HGU dan IUPHHK-HTI. Periode pengelolaan hutan dibagi menjadi dua, pertama IUPHHK-HTI seluas 40.000 ha yang dikelola PT. Inhutani (BUMN) sejak tahun 2002, dan periode IUPHHK HTI yang dikelola PT. Inhutani, PT. DSL (Swasta) dan PT. BRM (pihak swasta) [10]. Deforestasi hutan diperparah dengan adanya klaim kepemilikan hutan oleh masyarakat lokal sebagai hutan adat yang menyebabkan terjadinya konflik kepemilikan hutan di wilayah KPHP Dharmasraya.

Hasil penelitian pendahuluan terhadap kondisi hutan di wilayah kerja KPHP Dharmasraya menunjukkan bahwa tutupan hutan menurun dari $85 \%$ pada 2000 menjadi $18 \%$ pada tahun 2014 dari total wilayah KPHP Dharmasraya seluas sekitar 32.000 ha [11]. Diduga telah terjadi perambahan hutan oleh pihak tertentu serta kegagalan pengelolaan hutan ketika dikelola pihak swasta dan pemerintah baik melalui IUPHHK-HA dan IUPHHKHTI.

Dari latar belakang diatas, penelitian ini bertujuan untuk menganalisis faktor penarik dan pendorog deforestasi hutan di wilayah kerja KPHP Dharmasraya.

\section{Metode Penelitian}

\section{Waktu dan Lokasi Penelitian}

Pengumpulan data dimulai pada Januari hingga Juli 2017. Lokasi penelitian berada di KPHP Dharmasraya, Sumatera Barat. Secara administrasi KPHP Dharmasraya terletak di Kecamatan Pulau Punjung dan Koto Besar, Kabupaten Dhamasraya, Provinsi Sumatera Barat dengan luas sekitar 33.550 ha. Kawasan KPHP merupakan hutan sekunder lokasinya berdekatan dengan kawasan pemukiman penduduk, serta akses yang mudah dilalui melalui jalan darat dan jalan air. Secara keseluruhan wilayah KPHP Dharmasraya adalah hutan dataran rendah dengan topografi agak curam seluas 3.946 ha $(11.76 \%)$, datar seluas 16.171 ha $(48.20 \%)$ dan topografi landai seluas 13.433 ha (40.04\%).

\section{Pengumpulan Data, Pendekatan Penelitian, dan Analisis Data}

Pengumpulan data mengkombinasikan beberapa teknik pengumpulan data seperti wawancara key informant, observasi lapangan/transek, homestay di dalam hutan dan analisis data sekunder. Jumlah informan kunci yang diwawancarai sebanyak 34 informan yang terdiri dari KPHP Dharmasraya, Badan Pertanahan Nasional Dharmasraya, Dinas Kehutanan Kabupaten Dharmasraya, Perwakilan Nagari, Tokoh Adat, dan tokoh yang dianggap memiliki kapasitas sebagai informan. Metode penelitian menggunakan menggunakan pendekatan penelitian kualitatif. Afrizal (2015) menyatakan "Analisis data dalam penelitian kualitatif telah dilakukan mulai 
sejak merumuskan dan menjelaskan masalah, sebelum terjun ke lapangan, dan berlangsung terus sampai penulisan hasil penelitian [8] [12] [13]. Penelitian ini menggunakan analisis data model interaktif melalui tiga alur kegiatan, yaitu: 1) reduksi data, 2) display data, dan 3) penarikan kesimpulan/verifikasi [14]. Analisis data interaktif ditampilkan pada Gambar 1.

\section{Hasil dan Pembahasan}

\section{Sejarah Pengelolaan Hutan di Wilayah Kerja KPHP Dharmasraya}

Hutan produksi yang saat ini ditetapkan sebagai KPHP Dharmasraya memiliki sejarah panjang. Pada tahun 1972 izin hutan diberikan kepada PT. Ragusa dengan izin HPH dengan luas 66.000 ha. Masa berlaku HPH adalah 30 tahun hingga tahun 2002. Pada akhir tahun 1990an menjelang awal tahun 2000 wilayah HPH PT. Ragusa dibagi menjadi dua bagian, yaitu HP untuk HTI dan HGU1. Izin HPH tidak diperpanjang oleh pemerintah dengan alasan pengelolaan hutan yang kurang bertanggung jawab dan terjadi kerusakan hutan.

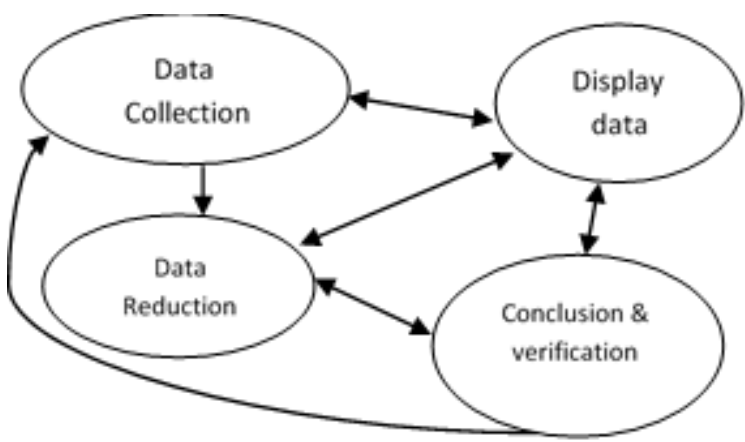

Gambar 1. Analisis data dan model interaktif

${ }^{1}$ Dokumen RPKHP KPHP Model Dharmasraya 2015 dan wawancara ketua KPH Dharmasraya, April 2016
Setelah berakhirnya HPH ini pada tahun 2002, sebagian area HPH ini menjadi hutanproduksi yang dapat dikonversi dan telah diberikan HGU nya kepada tigaperusahaan perkebunan besar swasta, yakti PT. Incasi Raya, PT. SMP dan PT.AWB sebuah perusaan swasta multinasional. Ketiga HGU ini mengusahakan tanaman sawit. Sisa HPH PT. Ragusa ini kemudian diberikan kepada tiga pemegang izin pemanfaaatan, yakni PT. Inhutani, PT. Dara Silva, dan PT.Bukit Raya Mudisa (BRM). Akan PT BRM unit berada di Kab. Solok Selatan yang sebagian wilayah pemanfaatanya berada di Kab. Dharmasraya. Oleh sebab itu keberadaan PT BRM tidak terpantau oleh KPHP Dharmasraya (Tabel 1), akan tetapi data izinnya tersedia pada BPKW I Medan.

Dari berbagai sumber diketahui bahwa PT. Inhutani akan menggarap 40.000 Hektar Lahan Kritis untuk HTI, seperti diberitakan dalam Harian Antara Rabu, 29, 1999/12:15:21 AM. PT (Persero) Inhutani IV Unit Sumatra Barat diberikan mandat menggarap sekitar 40.000 hektar lahan kritis bekas areal HPH milik PT Ragusa Ltd. di Koto Baru, Kabupaten Sawahlunto/Sijunjung untuk selanjutnya dijadikan Hutan Tanaman Industri (HTI) melalui Proyek Hutan Kemasyarakatan. HTI dikembangkan guna mengurangi ancaman terhadap penebangan dan perambahan liar oleh masyarakat sekitarnya. 
Tabel 1. Kawasan KPHP Dharmasraya menurut pemegang izin

\begin{tabular}{|c|c|c|}
\hline Izin & Pemegang Izin & Luas (Ha) \\
\hline \multirow[t]{4}{*}{$\begin{array}{l}\text { Blok HHK- } \\
\text { HT }\end{array}$} & $\begin{array}{l}\text { PT. Dara Silva } \\
\text { Lestari }\end{array}$ & 15461.91 \\
\hline & $\begin{array}{l}\text { PT.Bukit Raya } \\
\text { Mudisa }\end{array}$ & 764.09 \\
\hline & $\begin{array}{l}\text { PT.Inhutani IV } \\
\text { (Eks PT. } \\
\text { Ragusa) }\end{array}$ & 13721.68 \\
\hline & Sub Total & 29947.69 \\
\hline \multirow{2}{*}{$\begin{array}{l}\text { Belum } \\
\text { Berizin }\end{array}$} & Belum berizin & 2802.26 \\
\hline & Tidak diketahui & 4.16 \\
\hline \multicolumn{2}{|c|}{ Total luas KPHPDharmasraya } & 32.749 .95 \\
\hline
\end{tabular}

\section{Kekosongan Pengelolaan Hutan}

Meskipun hutan telah memiliki izin pengelolaan, praktek di lapangan izin pemanfaatan ini tidak berjalan dengan baik. PT. Inhutani tidak dapat dijumpai keberadaanya di wilayah $\mathrm{HTI}$, kemudian PT Dhara Silva telah memindahtangankan izin tersebut kepada PT. SMP, perusahaan perkebunan sawit yang berbatasan langsung dengan kawasan hutan berizin. Tidak ada aktifitas yang berarti yang telah dilaksanakan pemegang izin menyebabkan pendudukan oleh masyarakat lokal yang mengklaim hutan sebagai tanah ulayat. Apabila pemegang izin ingin melakukan aktifitas pengelolaan, otoritas adat meminta ganti rugi lahan dengan harga antara 5 - 10 juta per ha tergantung kondisi lahan yang akan dibebaskan dari pendudukan oleh masyarakat.

Perebutan hutan oleh masyarakat sesuai dengan kajian tentang pluralisme hukum dan sumberdaya alam dimana setiap individu dalam sebuah komunitas dapat mempergunakan berbagai starategi untuk mengklaim dan mendapatkan sumberdaya alam [15] [16]. Adanya pluralisme hukum diwilayah KPHP Dharmasraya memicu terjadinya forum shopping dimanamasyarakat menggunakan basis hukum dalam kaim kepemilikan hutan yang lebih berpihak pada kepentinganya [17] [11] [18]. Pada akhirnya, adanya pluralisme hukum memicu potensi konflik kepentingan dalam pengelolaan hutan antara masyarakat lokal dan negara [11] [19] [20].

Kemudian pada tahun 2013 kawasan $\mathrm{HTI}$ yang izinnya berada dibwah PT. Inhutani, PT. DSL dan PT. BRM ditetapkan sebagai wilayah KPHP Dharmasaraya. Pembentukan KPHP Model Dharmasraya berdasarkan usul Bupati Dharmasraya sesuai surat Nomor. 130/684/BPT/VIII-2013 Tgl. 2 Agustus 2013dan ditetapkan berdasarkan surat keputusan Menteri Kehutanan Republik IndonesiaNo. SK.695/Menhut-II/2013 tgl. 21 Oktober 2013 tentang Penetapan Wilayah Kesatuan Pengelolaan Hutan Produksi Model Dharmasraya (Unit VIII) yang terletak di Kecamatan Koto Besar dan Pulau Punjung Kabupaten Dharmasraya Provinsi Sumatra Barat denganluas lebih kurang $32.749 \mathrm{Ha}$. Secara geografis KPHP Model Dharmasraya terletak pada koordinat 010 03' 30" LS s/d 010 22' 00" LS dan 1010 24' 30" BT s/d 1010 38' 00"BT.

Tugas dan fungsi $\mathrm{KPH}$ adalah sebagai operator yang bertugas memastikan pengelolaan hutan sesuai dengan prinsip-prinsip yang telah ditetapkan pemerintah [21]. Terkait kewajiban pengelolaan dan pengamanan hutan masih menjadi wewenang perusahaan pemilik izin. Meskipun demikian, masuknya KPH sebagai operator pengelolaan hutan tidak memperbaiki kondisi hutan, tetap terjadi pendudukan hutan oleh masyarakat lokal. 


\section{Deforestasi dan Alih Fungsi Hutan menjadi Perkebunan}

Pada awal penelitian dilakukan analisis tutupan hutan sebagai indikator pengelolaan hutan diwilayah kerja KPHP Dharmasraya. Hasil yang diperoleh adalah deforestasi dan alih fungsi hutan yang sangat memprihatinkan di wilayah KPHP Dharmasraya. Hasil analisis citra satelit terhadap tutupan hutan di wilayah kerja KPHP Darmasraya sejak tahun 2000 menjelang habisnya HPH Ragusa, kondisi tutupan hutan masih relatif bagus, mencapai $86 \%$ kawasan berhutan dari total wilayah kerja KPHP Dharmasraya, dan luas lahan terbuka dan perkebunan masing-masing 3\% dan $10 \%$ dari tortal wilayah sekitar 32.749 ha .

Kemudian pada akhir tahun 2014 dilakukan kembali analisis tutupan hutan di wilayah kerja KPHP Dharmasraya menggunakan citra satelit, hasilnya tutupan hutan berubah sangat signifikan sejak tahun 2000. Pada tahun 2014, tutupan hutan tersisa $16 \%$ dari sebelumnya dari $86 \%$. Kemudian perkebunan (karet dan sawit) naik secara signifikan dari 10\% ditahun 2000 menjadi 59\% ditahun 2014 (Tabel 2). Kemudian lahan terbuka dan semak belukar (bekas tebangan hutan yang dibiarkan) masing-masing berjumlah $10 \%$ dan $12 \%$ dari luas 32.749 ha hutan di wilayah KPHP Dharmasraya.

Tabel 2. Perkembangan luas hutan wilayah kerja KPHP Dharmasraya tahun 20002014

\begin{tabular}{lrrrr}
\hline \multirow{2}{*}{ Tutupan Hutan } & \multicolumn{4}{c}{ \% dari luas 32.749 ha } \\
\cline { 2 - 5 } & 2000 & 2005 & 2011 & 2014 \\
\hline Hutan sekunder & 86.35 & 71.81 & 40.01 & 18.89 \\
Perkebunan & 10.24 & 23.61 & 52.91 & 59.00 \\
Lahan Terbuka/ & 3.41 & 4.58 & 7.08 & 22.11 \\
semak & & & & \\
\hline Total & $\mathbf{1 0 0}$ & $\mathbf{1 0 0}$ & $\mathbf{1 0 0}$ & $\mathbf{1 0 0}$ \\
\hline Sumber: Mutolib (2015) & & &
\end{tabular}

\section{Faktor Penarik Deforestasi Hutan}

Faktor penarik deforestasi dianalisis melalui faktor biofisik dan sifat ekonomi hutan. Faktor penarik yang meneyebabkan deforestasi meliputi: sifat ekonomi dan institusi sumberdaya hutan, serta mudahnya akses dan topografi hutan yang landai. Kedua faktor ini menyebabkan masyarakat tertarik menguasai hutan .

\section{Sifat ekonomi- institusi sumberdaya hutan}

Common-Pool Resources (CPRs) seperti laut, danau, sistem irigasi, "hutan", adalah sumberdaya yang dapat memenuhi kebutuhan manusia dan jumlahnya terbatas. Sehingga penggunaan SD oleh satu orang akan mengurangi dari jumlah unit sumber daya yang tersedia untuk orang lain. Kebanyakan sumber daya CPRs berukuran besar sehingga sejumlah orang dapat menggunakan sistem sumber daya secara bersamaan, sementara upaya untuk mengeluarkan orang-orang (to exclude) atau membatasinya (to limit) bersifat mahal [22] [23]. Karakteritik CPRs tersebut antara lain dapat disebabkan oleh ukuran sumberdaya alam itu semata, misalnya Gibson et al (2000) menyatakan bahwa pada kebanyakan hutan karena ukurannya yang luas menyebabkan kesulitan untuk mengatasi akses penunggang gelap (free riders) [24].

Berdasarkan sifat ekonomi-institusi barang, sebagian hutan wilayah kerja KPHP Dharmasraya memiliki karakteristik CPRs. Hutan di wilayah kerja KPHP Dharmasraya merupakan potensi untuk lahan pertanian danperkebunan yang memiliki areal kerja dengan ukuran yang sangat luas yaitu 32.749 ha. Masyarakat sekitar 
wilayah KPHP Dharmasraya merupan masyarakat yang bekerja disektor pertanian yang menempatkan lahan sebaai sumberdaya utama sebagai sumber pendapatan. Sifat ekonomi sumberdaya hutan di wilayah KPHP Dharmasraya baik dari kayu dan ketersediaan lahan menarik perambah dan pekebun untuk mas dan membuka perkebunan didalam hutan.

\section{Mudahnya akses dan topografi yang landai}

Faktor fisik yang mendukung deforestas dan perambahan di wilayah kerja KPHP Dharmasraya adalah akses masuk dalam wilayah kerja KPHP Dharmasraya cenderung mudah. Kendaraan roda dua dan empat dapat masuk kedalam hutan hingga bagian paling dalam [25]. Izin HPH Ragusa sejak tahun 1972 hingga 2002 telah berhasil membuka akses hutan. Untuk masuk kedalam hutan di wilah kerja KPHP Dharmasraya dapat melalui dua jalur. Jalur pertama dari Simpang Ragusa di Nagari Gunung Medan ditempuh sekitar 1 jam menggunakan kendaraan roda dua atau empat.

Jalur kedua, melalui Nagari Bonjol di Kecamatan Koto Besar. Dari Pulau Punjung, Nagari Bonjol dapat ditempuh menggunakan kendaraan roda dua dan empat dengan jarak tempuh $\pm 43 \mathrm{~km}$ selama \pm 1 jam. Kondisi jalan dari Pulau Punjung sampai dengan Jorong Bonjol mengikuti jalan provinsi dan kabupaten yang sudah baik.

Tabel 3. Tingkat aksesibilitas ke dalam kawasan KPHP Dharmasraya

\begin{tabular}{|l|r|}
\hline $\begin{array}{c}\text { Tingkat aksesibilitas ke } \\
\text { dalam kawasan }\end{array}$ & \multicolumn{1}{c|}{ Luas $\mathbf{( H a )}$} \\
\hline Rendah & $1,688.15$ \\
\hline Sedang & $15,440.73$ \\
\hline Tinggi & $16,186.24$ \\
\hline Tidak ada & 238.84 \\
\hline Total & $33.553,6$ \\
\hline
\end{tabular}

Sumber: RPHJP KPHP Dharmasraya, 2015
Selanjutnya dari Bonjol ke lokasi KPHP Dharmasraya bia ditempuh dalam waktu 30 sampai dengan 1 jam menggunakan kendaraan roda dua dan roda empat. Jalan menuju hutan di wialyah kerja KPHP Dharmasraya berupa jalan tanah yang sudah berbatu. Ditahun 2016, telah dibangun jembatan di Nagari Bonjol yang memudahkan kendaraan besar roda empat dapat masuk hmenuj hutan di wilayah kerja KPHP Dharmasraya. Aksesibilitas kedalam wilayah kerja KPHP Dharmasraya ditampilkan dalam Tabel 3.

Secara keseluruhan hutan di wilayah kerja KPHP Dharmasraya adalah hutan dataran rendah dengan topografi bergelombang. Laporan RPHJP KPHP Dharmasraya 2015 menyebutkan sebagian besar kawasan hutan di KPHP Dharmasraya memiliki topografi datar dan landai. Hal ini memudahkan masyarakat membuka jalan baru didalam hutan yang menyebabkan deforestasi dan perambahan hutan semakin cepat.

\section{Faktor Pendorong Deforestasi Hutan}

Terdapat beberapa faktor yang mendorong masyarakat membuka hutan. Salah satu motif utama adalah kebutuhan ekonomi yaitu melalui pembukaan hutan untuk lahan perkebunan. Selain tujuan membuka perkebunan, faktor yang mendorong masyarakat membuka hutan adalah pembukaan hutan untuk menandai hak milik. Setelah hutan ditebang kemudian ditinggalkan, dan tidak dijadikan perkebunan. meninggalkannya. Faktor pendorong deforestasi lainnya adalah tingginya kebutuhan kayu dannilai kayu sehingga masyarakat menebang kayu 
didalam hutan yang pada akhirnya menyebabkan deforestasi hutan.

\section{Pembukaan Hutan Untuk Perkebunan}

Perkebunan karet dan kelapa sawit didalam kawasan hutan di wilayah KPHP Dharmasraya berkembang dengan sangat cepat. Sejak 2000 dari total keseluruhan wilayah kerja KPHP Dharmasraya luas perkebunan baru mencapai 10\% tetapi akhir 2014 perkebunan telah mencapai $59 \%$ dan lahan terbuka dan semak bekas tebangan hutan mencapai 22\% (lihat Tabel 2). Hal ini menunjukkan bahwa upaya perambahan dan pembangunan perkebunan di areal KPHP Dharmasraya terus berlangsung hingga saat ini. Diperkiranan, dalam beberapa tahun kedepan hutan di wilayah kerja KPHP Dharmasraya akan habis dan berganti menjadi perkebunan.

Sektor perkebunan saat ini merupakan sektor yang menjanjikan. Selain itu lahan ketersediaan lahan di wilayah hutan masih sangat tinggi sehingga masyarakat berlomba-lomba membuka kebun didalam hutan.

\section{Pembukaan hutan untuk menandai hak milik}

Tidak sepenuhnya kegiatan perambahan dan penebangan hutan di wilayah KPHP Dharmasraya bertujuan untuk perkebunan atau pertanian. Banyak pihak yang membuka lahan hanya untuk menandai hak milik atas hutan. Setelah hutan dibersihkan masyarakat meninggalkan plot tanpa menanam tanaman apapun. Tujuan dari kegiatan ini adalah untuk mengklaim kepemilikan hutan agar tidak ambil pihak lain. Kemudian, masyarakat juga memiliki beberapa motif dan alasan kenapa melakukan hal ini yaitu 1) memastikan kepemilikan hutan untuk ditanami dimasa yang akan mendatang, 2) memastikan hak milik untuk dijual kepada pihak lain, dan 3) memperoleh kompensasi dari perusahaan pemilik $\mathrm{HTI}$ apabila perusahaan berniat merebut atau mengambil alih hutan atau lahan. Proses ini yang menyebabkan banyaknya tanah terlantar didalam hutan. Pembukaan untuk menandai hutan dipicu persaingan antar masyarakat karena masyarakat yang tidak segera membuka hutan (untuk menandai) tidak akan memperoleh lahan dengan lokasi yang strategis dan harga murah.

\section{Illegal logging}

Pengambilan kayu bukanlah suatu tindakan illegal apabila ditinjau dari aturan lokal (adat), pengambil kayu dapat mengambil kayu apabila sudah mendapat izin dari penguasa ulayat. Hutan di KPHP Dharmasraya secara umum terbagi dalam beberapa ulayat seperti ulayat Nagai Bonjol dan Sikabau, sehingga pengambil kayu harus meminta izin kepada penguasa lokal dimasing-masing wilayah.

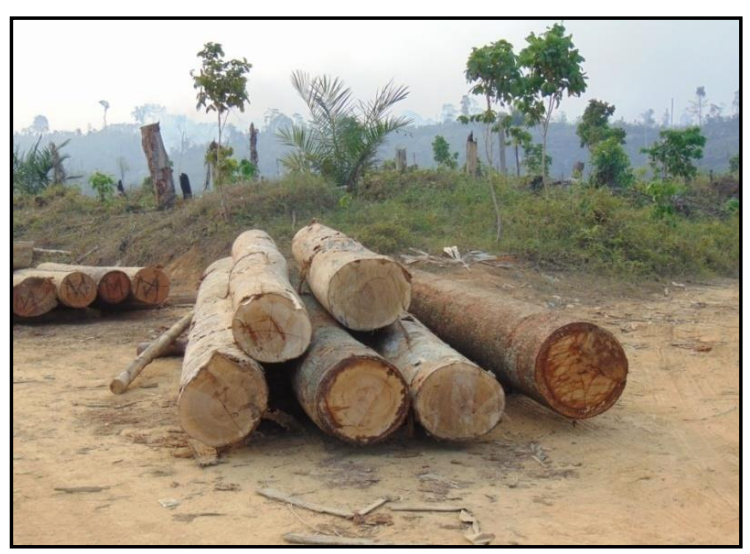

Gambar 3. Kayu hasil perambahan hutan di wilayah kerja KPHP Dharmasraya

Sumber: Observasi lapangan, 2017 
Kesepakatan umum yang terjadi antara pengambil kayu dan penguasa ulayat bermacam-macam. Diantaranya kesepakatan yang mengharuskan pembeli kayu membagi hasil kayu hutan kepada penguasa ulayat. Tetapi secara umum, penguasa ulayat hanya mensyaratkan pengambil kayu wajib membuka jalan didalam hutan menggunakan mesin eskavator dengan ketentuan tertentu. Pembukaan jalan bertujuan untuk memudahkan akses menuju hutan, terbukanya jalan akan meningkatkan harga jual lahan didalam hutan.

\section{Kesimpulan}

Hutan diwilayah KPHP Dharmasraya Sumatera Barat memiliki sejarah panjang dalam tata kelola. Saat ini hutan produksi hampir habis dan berganti menjadi perkebunan karet, kelapa sawit, dan semak belukar. Faktor penarik deforestasi hutan di KPHP Dharmasraya meliput sifat ekonomi dan institusi sumberdaya hutan, serta mudahnya akses dan topografi hutan yang landai. Faktor pendorong masyarakat melakukan penebangan hutan meliputi adalah kebutuhan ekonomi/lapangan kerja melalui pembukaan hutan untuk lahan perkebunan dan sumber pendapatan, pembukaan untuk menandai hak milik, serta Setelah hutan ditebang kemudian ditinggalkan, dan faktor lainnya adalah tingginya kebutuhan kayu dan nilai (harga) kayu sehingga masyarakat menebang kayu (illegal logging) didalam hutan yang pada akhirnya menyebabkan deforestasi hutan.

\section{Daftar Pustaka}

[1] J. K. Vanclay, "Deforestation: correlations, possible causes and some implications," Int. For. Rev., vol. 7, no. 4, pp. 278-293, 2005.

[2] Z. Ting, C. Haiyun, G. P. Shivakoti, R. Cochard, and K. Homcha-aim, "Revisit to community forest in northeast of Thailand: Changes in status and utilization," Environ. Dev. Sustain., vol. 13, no. 2, pp. 385402, 2011.

[3] E. L. Dalla-Nora, A. P. D. de Aguiar, D. M. Lapola, and G. Woltjer, "Why have land use change models for the Amazon failed to capture the amount of deforestation over the last decade?," Land use policy, vol. 39, pp. 403-411, 2014.

[4] L. E. O. . Aragao et al., "Interactions between rainfall, deforestation and fires during recent years in the Brazilian Amazonia," Philos. Trans. R. Soc. B Biol. Sci., vol. 363, no. 1498, pp. 1779-1785, 2008.

[5] B. A. Margono, P. V Potapov, S. Turubanova, F. Stolle, and M. C. Hansen, "Primary forest cover loss in Indonesia over 2000-2012," Nat. Clim. Chang., vol. 4, no. June, pp. 1-6, 2014.

[6] H. J. Geist and E. F. Lambin, "Proximate Causes and Underlying Driving Forces of Tropical Deforestation," Bioscience, vol. 52, no. 2, p. 143, 2002.

[7] H. Purnomo et al., "Fire economy and actor network of forest and land fires in Indonesia," For. Policy Econ., vol. 78, pp. 21-31, 2017.

[8] Afrizal, "Final Report: A preliminary assesment of redd governance for Tesso Nilo landscape," Padang, 2009.

[9] C. P. . Purba et al., Potret Keadaan Indonesia Periode 2009-2013. Bogo: Forest Watch Indonesia, 2014.

[10] A. Mutolib, Yonariza, Mahdi, and $\mathrm{H}$. Ismono, "Gender Inequality and the Oppression of Women within 
Minangkabau Matrilineal Society: A Case Study of the Management of Ulayat Forest Land in Nagari Bonjol, Dharmasraya District, West Sumatra Province, Indonesia," Asian women, vol. 32, no. 3, pp. 2349, 2016.

[11] A. Mutolib, Yonariza, Mahdi, and H. Ismono, "Forest ownership conflict between a local community and the state: A case study in Dharmasraya, Indonesia," J. Trop. For. Sci., vol. 29, no. 2, pp. 163-171, 2017.

[12] Afrizal, Metode Penelitian Kualitatif: Sebuah Upaya Mendukung Penggunaan Penelitian Kualitatif dalam Berbagai Disiplin IImu. Jakarta: Raja Grafindo Persada., 2015.

[13] B. Afifuddin and S. Ahmad, Metodologi Penelitian Kualitatif. Bandung: Pustaka Setia, 2009.

[14] M. Matthew B, H. A M, and S. Johnny, Qualitative data analysis : a methods sourcebook, Third edit. Thousand Oaks, Califorinia: SAGE Publications, 2014.

[15] R. R. Devkota, A. Maryudi, and M. Krott, "Paradoxes of Community Forestry: Formal Devolution Covering Informal Expansion of State Control - Cases from Nepal and Indonesia," Geottingen, 2010.

[16] B. D. Ratner, R. Meinzen-Dick, C. May, and E. Haglund, "Resource conflict, collective action, and resilience: An analytical framework," Int. J. Commons, vol. 7, no. 1, pp. 183-208, 2013.

[17] Ministry of Operasionalisasi

Forestry, Kesatuan Pengelolaan Hutan ( $\mathrm{KPH}$ ): Langkah Awal Menuju Kemandirian Editor:, 3rd ed. Yogyakarta: Kanisius, 2014.

[18] F. v. Benda-Beckmann and K. v. Benda-Beckmann, "How communal is communal and whose communal is it? Lesson from Minangkabau.," in Changing properties of property, Yew York: Berghan Books, 2006, pp. 194-217.

[19] A. Mutolib, Yonariza, H. Ismono, and Mahdi, "Agrarian Conflict and Communal Land Release: A Case Study of Melayu Tribe in Forest Management Unit Dharmasraya, West Sumatra," J. Penelit. Sos. dan Ekon. Kehutan., vol. 12, no. 3, pp. 213-225, 2015.

[20] A. Mutolib, Yonariza, Mahdi, and $\mathrm{H}$. Ismono, "Gender inequality and the oppression of women within minangkabau matrilineal society: A Case study of the management of ulayat forest land in nagari bonjol, dharmasraya district, west sumatra province, Indonesia," Asian Women, vol. 32, no. 3, pp. 23-49, 2016.

[21] Ministry of Forestry, Pembangunan Kesatuan Pengelolaan Hutan, 1st ed. Jakarta: Pembangunan Kesatuan Pengelolaan Hutan $(\mathrm{KPH})$ : Konsep, Peraturan Perundangan dan Implementasi, 2011.

[22] A. Hamlin, E. Ostrom, R. Gardner, and J. Walter, "Rules, Games, and Common-Pool Resources.," Econ. J., vol. 105, no. 431, p. 1034, 1995.

[23] G. Varughese and E. Ostrom, "The contested role of heterogeneity in collective action: Some evidence from community forestry in Nepal," World Dev., vol. 29, no. 5, pp. 747765, 2001.

[24] C. C. Gibson, M. A. McKean, and E. Ostrom, "Explaining Deforestation: The Role of Local Institutions," in People and Forests: Communities, Institutions and Governance, C. Gibson, M. A. McKean, and E. Ostrom, Eds. massachusetts: MIT 
Abdul Mutolib dkk. : Faktor Penarik dan Pendorong Deforestasi Hutan di Kabupaten Dharmasraya, Sumatra Barat

Press, 2000, p. 1-26 (274).

[25] J. C. Ribot and N. L. Peluso, "A

Theory of Access*," Rural Sociol.,

vol. 68, no. 2, pp. 153-181, 2009. 